\title{
Serum gastrin level in early childhood
}

\author{
L. SANN, J. A. P. CHAYVIALLE, A. BREMOND, and R. LAMBERT \\ From Pavillon $S$ bis, and Laboratoire de Physiopathologie Digestive, INSERM U 45, Pavillon H bis, Hôpital \\ Edouard-Herriot, Lyon, France
}

Sann, L., Chayvialle, J. A. P., Bremond, A., and Lambert, R. (1975). Archives of Disease in Childhood, 50, 782. Serum gastrin level in early childhood. Serum gastrin concentration was measured in newborns and infants with no gastrointestinal disorders, in the fasting state and after food stimulation. Mean fasting concentration in 14 newborns aged 1 to 12 days $(130.4 \mathrm{pg} / \mathrm{ml} \pm 11.4 \mathrm{SE})$ was significantly higher than the mean value in 23 infants aged 1.5 to 22 months $(101.4 \pm 6.6 \mathrm{pg} / \mathrm{ml})$. Ingestion of the usual milk meal resulted in a definite rise of the serum gastrin level in the 5 subjects tested ( 3 newborns and 2 infants). The mean fasting serum gastrin level in 6 babies with hiatus hernia and gastro-oesophageal reflux was found to be no different from the corresponding value in 8 age-matched controls. However, a conspicuously raised fasting gastrin concentration was observed in one infant with lower oesophageal dyskinesia.

The results indicate that the release of gastrin and the reactivity of the hormoneproducing sites to food stimulation in early life are similar to those in adult humans. No defect of gastrin release was shown in patients with gastro-oesophageal reflux.

Lower oesophageal sphincter incompetence is a common condition in early life (Forshall, 1955). The sphincter tone has been reported to be lower in newborns than in adults (Gryboski, Thayer, and Spiro, 1963). Recent experimental studies suggested that the polypeptide hormone gastrin, a potent stimulant of gastric acid secretion (Edkins, 1905), might play a role in the control of sphincter pressure (Castell, 1970; Cohen and Lipshutz, 1971). However, the secretion, serum level, and metabolism of gastrin have been little investigated in newborns and infants. The aim of the present study was to measure fasting and food-stimulated serum gastrin levels in normal newborns and infants, as well as in infants with clinical gastro-oesophageal disorders.

\section{Subjects and methods}

Fasting normal subjects. Fasting serum gastrin level was studied in 46 hospital controls with no detectable gastrointestinal or renal disorder who were divided into three groups according to age. The first group included 23 infants aged 1.5 to 22 months (median $6 \mathrm{~m}$ ), weighing 4.1 to $13.5 \mathrm{~kg}$, who were given 6 to 4 meals per day according to age. The second group included 14 newborns aged 1 to 12 days, weighing

Received 6 February 1975.
1680 to $3600 \mathrm{~g}$, whose gestational ages were 34 weeks 1 , 36 to 38 weeks 4 , and 39 to 41 weeks 9 . All were given 6 feeds per day. The last group included 9 normal term newborns in whom arterial and venous cord blood was simultaneously collected immediately after delivery (Table I). Other blood samples from the control

\section{TABLE I}

Serum gastrin concentrations in corresponding arterial and venous cord sera collected from 9 normal term newborns immediately after birth

\begin{tabular}{c|c}
\hline \multicolumn{2}{c}{ Serum gastrin level $(\mathrm{pg} / \mathrm{ml})$} \\
\hline Arterial & Venous \\
\hline 155 & 154 \\
79 & 98 \\
90 & 105 \\
110 & 108 \\
111 & 116 \\
261 & 296 \\
50 & 60 \\
101 & 90 \\
60 & 55 \\
\end{tabular}

infants were taken at the same time as blood was being drawn for other clinical purposes.

Fasting patients with gastro-oesophageal disorders. The resting serum gastrin level was studied 
in 7 babies with gastro-oesophageal abnormalities (Table II). Serum gastrin concentrations in these patients were compared to the values in corresponding age-matched controls (aged 2 to $10 \mathrm{w}$ ).

\section{TABLE II}

Fasting serum gastrin concentrations in 7 babies with clinical gastro-oesophageal disorders. Mean ( $\pm S E$ ) gastrin level in 8 age-matched controls was $123 \pm$ $15 \cdot 1 \mathrm{pg} / \mathrm{ml}$ (range 60-186)

\begin{tabular}{l|c|c}
\hline \multicolumn{1}{c|}{ Diagnosis } & Age (w) & $\begin{array}{c}\text { Serum gastrin level } \\
(\mathbf{p g} / \mathbf{m l})\end{array}$ \\
\hline $\begin{array}{l}\text { Lower oesophageal } \\
\text { dyskinesia }\end{array}$ & 10 & \\
Hiatus hernia and & 2 & 315 \\
gastro-oesophageal & 4 & 211 \\
reflux & 4 & 100 \\
& 6 & 105 \\
& 6 & 54 \\
& 10 & 163 \\
\hline
\end{tabular}

Mean $\pm S E 125 \cdot 2 \pm 54 \cdot 7$

Gastrin response to food stimulation. Gastrin response to food stimulation was studied in 5 controls ( 3 newborns and 2 infants), in 2 infants with hiatus hernia and gastro-oesophageal reflux, and in 1 infant with lower oesophageal dyskinesia. The meal consisted of $70-160 \mathrm{ml}$ of a $15-17 \%(\mathrm{w} / \mathrm{v})$ solution of milk powder in water (Nido, Nestlé) according to age. $2 \mathrm{ml}$ blood samples were collected immediately before, and 2, 5, 10 , and 20 minutes after the meal.

Measurement of serum gastrin level. Sera were kept at $-40^{\circ} \mathrm{C}$ until tested. Gastrin was measured with a double-antibody radioimmunoassay method (Ganguli and Hunter, 1972), using a rabbit antigastrin serum (a gift of Dr P. C. Ganguli, Manchester) and natural porcine gastrin (a gift of Dr R. A. Gregory, Liverpool) as standard and for iodination. Sensitivity of the assay was $15 \mathrm{pg} / \mathrm{ml}$ of serum. Precision at the sensitivity threshold was $4 \cdot 8 \%$ (coefficient of variation of 8 replicates). The within-assay and between-assay variations, estimated by assaying 17 samples twice in the same assay or in 2 different assays, were respectively $8 \cdot 2$ and $6.9 \%$ (coefficient of variation). All serum samples were tested at 2 (usually $1 / 5$ and $1 / 10$ ) or more dilutions in duplicates.

Statistical analysis. Student's ' $t$ ' test and correlation coefficient were used for statistical evaluation of the data (Snedecor, 1956).

\section{Results}

Fasting serum gastrin concentration. Mean ( $\pm \mathrm{SE}$ ) fasting serum gastrin level in the infants was $101 \cdot 4 \pm 6 \cdot 6 \mathrm{pg} / \mathrm{ml}$ (range 55-186). There was no correlation between the gastrin concentration and either age or weight. Mean value in the newborns was $130 \cdot 4 \pm 11 \cdot 4 \mathrm{pg} / \mathrm{ml}$ (range 69-190). Again, no correlation was observed between gastrin level and gestational age, weight, or chronological age in this group, but the mean level in the newborns was significantly higher than the value in the infants $(\mathrm{P}<0 \cdot 05)$. In the 9 term newborns studied immediately after birth, the serum gastrin levels in corresponding arterial and venous cord sera were not significantly different (Table I). Among the patients with gastro-oesophageal disorders, the fasting serum gastrin levels in the 6 babies with hiatus hernia and reflux ranged from 54-211 pg/ml (Table II), while the value in the patient with lower oesophageal dyskinesia was clearly higher (315 $\mathrm{pg} / \mathrm{ml}$ ). Mean serum gastrin concentration in the 6 babies with hiatus hernia and gastro-oesophageal reflux $(125 \cdot 2 \pm 54 \cdot 7 \mathrm{pg} / \mathrm{ml})$ was not significantly different from the mean value in the 8 age-matched controls $(123 \cdot 0 \pm 15 \cdot 1 \mathrm{pg} / \mathrm{ml}$, range $60-186)$.

Gastrin response to food stimulation. Ingestion of the milk meal resulted in a definite rise of the serum gastrin level in the 5 normal subjects tested (Fig.). Expressed as percentage increase
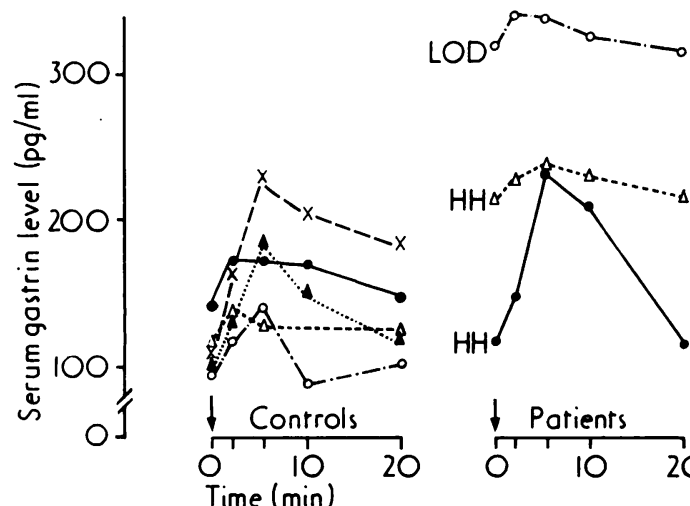

FIG.-Effect of ingestion of the usual milk on serum gastrin level in 5 normal newborns and infants (controls) and in 3 infants with $(\mathrm{HH})$ hiatus hernia and gastro-oesophageal reflux or (LOD) lower oesophageal dyskinesia. Arrows indicate food ingestion.

above basal values, the mean rises at 2 and 5 minutes after the meal were 28 and $55 \%$, respectively. In most subjects serum gastrin concentrations were back to near-basal values 20 minutes after the meal. The same stimulus resulted in a moderate response in 2 of the 3 patients with gastro-oesophageal disorders, 9 and $7 \%$ respectively above basal value 5 min after meal), while a greater response $(+95 \%$ at $5 \mathrm{~min}$ ) was observed in the last patient (Fig.). 


\section{Discussion}

Little information is available on the metabolism of gastrin during the first hours of life. The $p H$ of the gastric contents immediately after birth was reported to be high (Ebers, Smith, and Gibbs, 1956), and has been ascribed to prior ingestion of amniotic fluid by the fetus (Ahn and Kim, 1963). Subsequent washing of the gastric mucosa was shown to result in a fall of the intragastric $p H$ (Avery, Randolph, and Weaver, 1966), thus indicating that a significant resting acid secretion was present in the normal term newborn. It has been proposed that persistence of maternal gastrin in the child could be one of the mechanisms for acid secretion during the first hours of life (Silverman, Roy, and Cozetto, 1971). This hypothesis is supported by the present results. Arterial and venous gastrin concentrations in 9 pairs of cord sera were similar, suggesting that circulating gastrin in newborns immediately after birth may be mainly of maternal origin. Nevertheless, a significant secretion of gastrin by the fetus cannot be excluded by the results of the present study.

Recent observations in animals indicated that the gastrin-producing sites were immature during the first weeks of life, since the gastrin concentration in antral mucosa in the newborns was lower than the value in adult controls (Larsson et al., 1974). That this may not be the case in humans is suggested in the present study, where a measurable amount of gastrin was observed in all 14 normal newborns aged 1 to 12 days. Furthermore, the mean serum gastrin level in these subjects appeared to be higher than the mean value in 60 normal adults studied in this laboratory $(67 \pm 2 \cdot 6 \mathrm{pg} / \mathrm{ml}$, unpublished results), thus suggesting that gastrin may be of physiological importance in early life. The fasting serum gastrin level in normal infants was lower than the value in newborns. Whether this was due to more frequent feeding in the latter group is unlikely, since no significant difference was found between the gastrin level in infants given 6 meals per day and the value in those fed only 4 meals a day. In adult humans the fasting serum gastrin level has been shown to be inversely related to the acid secretion rate (Trudeau and McGuigan, 1971), this being ascribed to the feed-back between antral acidification and gastrin release (Woodward et al., 1954). Previous acid secretion studies in newborns and infants have shown a progressive rise of the acid secretion rate during the first months of life (Ghai et al., 1965; Rødbro et al., 1966; Agunod et al., 1969; Micheli, 1969). Although no acid secretion study was performed in the present subjects, it is likely that the difference between the fasting serum gastrin levels in newborns and in infants was due to different acid secretion rates.

Gastro-oesophageal reflux is a common condition in newborns, especially during the first weeks of life (Lantuejoul, Heraud, and Cernes, 1955; Forshall, 1955). The lower oesophageal sphincter (LES) tone is lower in newborns and infants than in adults (Gryboski et al., 1963). Since a significant rise of the LES pressure has been observed after pentagastrin injection or intragastric instillation of alkali, a supposed gastrin-releasing factor, it has been suggested that endogenous gastrin might play a role in the control of LES function in man and animal (Castell, 1970; Lipshutz et al., 1973). In the present study the fasting serum gastrin level was studied comparatively in normal newborns and infants. The gastrin concentration was higher in the subjects aged 1 to 12 days at a time when chalasia is most frequently observed (Lantuejoul et al., 1955). In addition, the fasting serum gastrin level in patients with hiatus hernia and gastrooesophageal reflux was not different from the value in age-matched controls. It thus appears that LES incompetence in early life cannot be ascribed to a defect of gastrin release. Whether abnormalities of the LES tone in human newborns are due to altered reactivity of the sphincter muscle to circulating gastrin, as shown in animals (Cohen, 1974) remains to be investigated.

The diagnosis of lower oesophageal dyskinesia or cardiospasm was established in one infant according to the usual clinical and radiological criteria (Roviralta, 1967; Caffey, 1973). In this patient resting serum gastrin level was clearly higher than those in the corresponding age-matched controls, and food stimulation resulted in a limited rise of gastrin concentration. The significance and pathophysiology of lower oesophageal dyskinesia are not yet fully understood. Whether gastrin plays a role in the genesis of this disorder deserves further investigation.

While this manuscript was being reviewed, Rogers et al. (1974) reported a study of the resting serum gastrin level in 19 4-day-old newborns. The results obtained in the newborns of the present study are close to the gastrin concentrations observed in their group (mean gastrin level $151 \pm 15 \cdot 8 \mathrm{pg} / \mathrm{ml}$ ).

We thank Sister Tarasquini for collecting the samples, Miss C. Crozier for expert technical assistance, and Dr D. Morris for reviewing the manuscript.

\section{REFERENCES}

Agunod, M., Yamaguchi, N., Lopez, R., Luhby, A. L., and Glass G. B. J. (1969). Correlative study of hydrochloric acid, pepsin and intrinsic factor secretion in newborns and infants. American Fournal of Digestive Diseases, 14, 400. 
Ahn, C. J., and Kim, Y. J. (1963). Acidity and volume of gastric contents in the first week of life. Fournal of the Korean Medical Association, 6, 72.

Avery, G. B., Randolph, J. G., and Weaver, T. (1966). Gastric acidity in the first day of life. Pediatrics, 37, 1004.

Caffey, J. (1973). Pediatric X-ray Diagnosis, p. 597. Year Book Medical Publishers, Chicago.

Castell, D. O. (1970). Hormonal control of gastroeosophageal sphincter strength. New England fournal of Medicine, 282, 886.

Cohen, S. (1974). Development characteristics of lower esophageal sphincter function: a possible mechanism for infantile chalasia. Gastroenterology, 67, 252.

Cohen, S., and Lipshutz, W. (1971). Hormonal regulation of human lower esophageal sphincter competence: the interaction of gastrin and secretin. Fournal of Clinical Investigation, 50, 449.

Ebers, D. W., Smith, D. I., and Gibbs, G. E. (1956). Gastric acidity on the first day of life. Pediatrics, 18, 800 .

Edkins, J. S. (1905). On the chemical mechanism of gastric secretion. Proceedings of the Royal Society. Series B, Biological Sciences, 76, 376.

Forshall, I. (1955). The cardio-oesophageal syndrome in childhood. Archives of Disease in Childhood, 30, 46.

Ganguli, P. C. and Hunter, W. M. (1972). Radio-immunoassay of gastrin in human plasma. Fournal of Physiology, 220, 499.

Ghai, O. P., Singh, N. M., Walia, B. N. S., and Gadekar, N. G. (1965). An assessment of gastric acid secretory response with 'maximal' augmented histamine stimulation in children with peptic ulcer. Archives of Disease in Childhood, 40, 77.

Gryboski, J. D., Thayer, W., and Spiro, A. (1963). Esophageal motility in infants and children. Pediatrics, 31, 382.

Lantuejoul, P., Heraux, A., and Cernes, M. (1955). Le reflux gastro-oesophagien chez le nouveau-né. Nourrisson, 43, 53.
Larsson, L. I., Hakanson, R., Rehfeld, J. F., Stadil, F., and Sundler, F. (1974). Occurrence and neonatal development of gastrin immunoreactivity in the digestive tract of the rat. Cell and Tissue Research, 149, 275.

Lipshutz, W. H., Gaskins, R. D., Lukash, W. M., and Sode, J. (1973). Pathogenesis of lower-esophageal-sphincter incompetance. New England fournal of Medicine, 289, 182.

Micheli, H. (1969). La stimulation gastrique maximale à l'histamine chez l'enfant normal. Helvetica Paediatrica Acta, 24, 278.

Rødbro, P., Krasilnikoff, P., Christiansen, P. M., and Bitsch, V. (1966). Gastric secretion in early childhood. Lancet, 2, 730

Rogers, I. M., Davidson, D. C., Lawrence, J., Ardill, J., and Buchanan, K. D. (1974). Neonatal secretion of gastrin and glucagon. Archives of Disease in Childhood, 49, 796.

Roviralta, E. (1967). Hernies Hiatales et Ectopies Partielles de l'Estomac Chez l'Enfant, p. 67. Masson, Paris.

Silverman, A., Roy, C. C., and Cozetto, F. J. (1971). Pediatric Clinical Gastroenterology, p. 528. Mosby, Saint Louis.

Snedecor, G. W. (1956). Statistical Methods, 5th ed. Iowa State University Press, Ames.

Trudeau, W. L., and McGuigan, J. E. (1971). Relation between serum gastrin levels and rates of gastric hydrochloric acid secretion. New England fournal of Medicine, 284, 408.

Woodward, E. R., Lyon, E. S., Landor, J., and Dragstedt, L. R. (1954). The physiology of the gastric antrum. Experimental studies on isolated antrum pouches in dogs. Gastroenterology, 27, 766.

Correspondence to Dr L. Sann, Laboratoire de Physiopathologie Digestive, INSERM U 45, Pavillon H bis, Hôpital Edouard-Herriot, 69374 Lyon, France. 